\title{
POLITIK DAN KAUM FEMINIS
}

\author{
Audra Jovani \\ audrajovani@yahoo.com
}

\begin{abstract}
Feminist theory attempted to analyze the various conditions that shape the lives of women and explore diverse cultural understanding about women. Feminist theory was originally directed to the political objective of the Woman Movement. The feminist rejected the view that the inequality between men and women are naturally. Thinking as a feminist involves attempts to challenge many of the things that are considered as "knowledge". Historically, live in a society dominated by men, women are more often made into objects rather than the creator of knowledge. As the result, many things are passed down as an objective knowledge about the world is actually produced by men (white skin, middle class and heterogeneous). Women are in a variety of different positions in local and global contexts and displayed differently in art, literature and other media; the different in terms of nationality, ethnicity, education, language, class, family, work, ability or disability and sexuality is crucial.
\end{abstract}

Keywords: Politics, Feminism, Feminist

\section{Konteks Historis}

Akhir 1960-an dan awal 1970-an menjadi saksi meningkatnya aktivitisme kaum kiri di seluruh dunia Barat. Inilah konteks kemunculan Gerakan Pembebasan Perempuan, bersamaan dengan gerakan-gerakan lain seperti Gay Liberation dan Black Power. Karya kaum feminis pada masa ini terinspirasi oleh aktivisme akar rumput kendati sebagian besar ditulis oleh perempuan muda, kulit putih dan berpendidikan universitas. Teori feminisme awal ini didasari oleh kebutuhan untuk memahami penyebab ketertindasan perempuan dengan tujuan menjungkirbalikkan tatanan sosial yang didominasi oleh laki-laki.

Di Amerika Serikat, dua karya perintis yang kemudian dikenal sebagai feminisme radikal diterbitkan pada tahun 1970: Sexual Politics (Millett, 1970), The Dialectic of Sex: The Case for Feminist Revolution (Firestone, 1970). Saat itu, feminisme juga memiliki pengaruh dalam lembaga-lembaga akademis. Banyak aktivis dalam gerakan feminisme juga merupakan mahasiswa, dosen dan peneliti dan mulai membawa keprihatinan feminis ke dalam karya akademis. Dunia akademis sendiri merupakan arena perjuangan kaum feminis. Kaum perempuan masih menjadi minoritas kecil di kalangan pemegang posisi akademis yang mapan dan kaum 
feminis merupakan kelompok marjinal yang tidak memiliki kekuatan dan baru berkembang, namun memiliki kecakapan politik yang berasal dari aktivisme.

Dalam berbagai disiplin ilmu yang sudah mapan, kaum perempuan mengadakan pertemuan dan berbagai gagasan dengan tujuan memasukan pengetahuan dan cara berpikir feminis ke dalam agenda. ${ }^{1}$ Feminisme sebagai kegiatan politik akar rumput tidak hilang, kaum perempuan tetap aktif hingga sekarang dalam kampanye-kampanye dengan isu tunggal seputar pornografi, hak reproduksi, kekerasan terhadap perempuan dan hal-hal legal perempuan. Seiring dengan perubahan yang dihasilkan oleh politik feminis, teori feminis juga dipengaruhi oleh perkembangan akademis, berbagai bentuk teori baru dan pergeseran hirarki disiplin. Dengan berkembangnya perspektif postrukturalis dan postmodern yang menekankan ketidakstabilan bahasa dan makna, pengaruh perspektif ilmu sosial dalam teori feminis semakin memudar.

Politik adalah praktik (usaha menggapai kehidupan yang baik) dan merupakan studi tentang kekuasaan untuk memerintah. Praktik yang dimaksudkan adalah mencakup penggunaan, pengaturan, tekanan terhadap pemerintah dan juga perlawanan terhadap pemerintahan dan kekuasaannya. Menurut kalangan feminis maupun kalangan ortodoks, politik merupakan istilah yang sangat sulit didefinisikan meskipun istilah tersebut biasa digunakan, tidaklah mudah mengatakan dengan tepat apa maknanya ketika suatu tindakan, peristiwa atau relasi digambarkan sebagai bersifat politik (Agnes Heller, 1991).

\section{Definisi Politik}

Politik adalah usaha menggapai kehidupan yang baik, di Indonesia kita mengenalnya dengan pepatah gemah ripah loh jinawi, Plato dan Aristoteles (Yunani Kuno) menamakannya sebagai en dam onia atau the good life. Sejak dahulu kala masyarakat mengatur kehidupan kolektif dengan baik karena masyarakat sering menghadapi keterbatasan sumber alam dan perlu mencari satu cara agar semua kebutuhan warga dapat dipenuhi dan merasa bahagia dan puas.

1 Sosiologi merupakan contoh yang baik karena bidang ini merupakan salah satu disiplin pertama dimana feminisme memberikan pengaruh nyata. Peristiwa yang penting adalah konferensi Asosiasi Sosiologi Inggris (British Sociological Association - BSA) pada 1974, yang diselenggarakan dengan tema "Pembagian Seksual dalam Masyarakat". Selanjutnya, Women's Caucus and Sexual Divisions Study Group didirikan untuk memastikan agar perempuan mendapat perwakilan yang layak dalam BSA dan agar gagasan-gagasan feminis mulai diperhatiakan secara lebih luas dalam disiplin soisologi secara keseluruhan. Perempuan dalam sosiologi terlibat dalam mengkampanyekan adanya kuliah tentang perempuan dalam disiplin tersebut dan juga berperan penting dalam membentuk Kajian Perempuan sebagai bidang akademis sendiri. 
Untuk mencapai tujuan tersebut dapat dilakukan dengan berbagai cara, yang terkadang bertentangan satu dengan lainnya. Dan tujuan tersebut hanya dapat dicapai jika memiliki kekuasaan, dan kekuasaan itu perlu dijabarkan dalam keputusan mengenai kebijakan yang akan menentukan pembagian (alokasi) dari sumber daya yang ada.

Politik dalam suatu Negara (state) berkaitan dengan masalah kekuasaan (power), pengambilan keputusan (decision making), kebijakan publik (publik policy) dan alokasi atau distribusi (allocation and distribution). Pemikiran mengenai politik di dunia Barat banyak dipengaruhi oleh fisuf Yunani Kuno abad ke 5 SM. Plato dan Aristoteles menganggap politik sebagai suatu usaha untuk mencapai masyarakat politik yang terbaik. Di dalam politik tersebut, manusia akan hidup bahagia karena memiliki peluang untuk mengembangkan bakat, bergaul dan hidup dalam suasana moralitas yang tinggi. Usaha menggapai the good life menyangkut bermacam-macam kegiatan, menyangkut proses penentuan tujuan dari system serta cara-cara melaksanakan tujuan. Masyarakat mengambil keputusan mengenai apakah yang menjadi tujuan dari system politik dan menyangkut pilihan antara beberapa alternative serta urutan prioritas dari tujuantujuan yang telah ditentukan.

Untuk melaksanakan kebijakan-kebijakan umum yang menyangkut pengaturan dan alokasi dari sumber daya alam, perlu dimiliki kekuasaan serta wewenang. Kekuasaan ini diperlukan baik untuk membina kerja sama maupun untuk menyelesaikan konflik yang mungkin timbul dalam proses ini. Cara-cara yang dipakai dapat bersifat persuasi dan paksaan (coercion). Tanpa unsur paksaan, kebijakan hanya merupakan perumusan keinginan (statament of intent) belaka. Kegiatan-kegiatan dapat menimbulkan konflik karena nilai-nilai baik materil maupun mental yang dikejar sifatnya langka. Di negara demokrasi, kegiatan ini memerlukan kerja sama karena kehidupan manusia bersifat kolektif. Dan dalam rangka ini, politik pada dasarnya dapat dilihat sebagai usaha penyelesaian konflik (conflict resolution) atau consensus (consensus).

Dalam kegiatan politik, terdapat segi-segi positif dan juga segi-segi yang negatif, segi negatif ini disebabkan karena politik mencerminkan tabiat manusia, baik nalurinya yang baik maupun nalurinya yang buruk. Perasaan manusia yng beraneka ragam sifatnya, sangat mendalam dan sering saling bertentangan, mencakup rasa cinta, benci, setia, bangga, malu dan marah. ${ }^{2}$ Tidak heran jika dalam realitas sehari-hari sering kali berhadapan dengan banyak kegiatan yang tidak terpuji "Politik, dalam berntuk yang paling buruk, adalah perebutan

\footnotetext{
2 David E. Apter. 1985. "Pengantar Analisa Politik". Jakarta: LP3ES, hal. 5.
} 
kekuasaan, kekuasaan dan kekayaan untuk kepentingan diri sendiri (politics at its worst is a selfish grab for power, glory and riches) ${ }^{3}$ Singkatnya, politik adalah perebutan kuasa, tahta dan harta.

Definisi politik yang berkaitan dengan masalah konflik dan konsensus:

1. Politik adalah kegiatan yang menyangkut cara bagaimana kelompokkelompok mencapai keputusan-keputusan yang bersifat kolektif dan mengikat melalui usaha untuk mendamaikan perbedaan-perbedaan diantara anggotaanggotanya (politics is the activity by which groups reach binding collective decision through attempting to reconcile among their members). ${ }^{4}$

2. Politik adalah kegiatan suatu bangsa yang bertujuan untuk membuat, mempertahankan dan mengamandenkan peraturan-peraturan umum yang mengatur kehidupannya, yang berarti tidak dapat terlepas dari gejala konflik dan kerja sama (politics is the activity through which a people make, preserve and amend the general rules under which they live and such is inextricably linked to the phenomen of conflict and cooperation $)^{5}$

Slogan politik yang paling sering didengung-dengungkan dalam gerakan perempuan Barat selama tiga puluh tahun belakangan ini adalah "yang personal itu politis (personal is politics)" telah membuat bingung para teoretisi politik lakilaki dan mereka menganggap slogan tersebut tidak masuk akal, kurang konsisten, memiliki implikasi totalitarian dan seterusnya.

Menurut beberapa teoretisi, definisi politik adalah praktek memerintah dengan cara tertentu; memerintah "secara politis" adalah memerintah dengan mekanisme selain kekerasan, melalui berbagai lembaga dan pengaturan yang bersifat publik dan mengacu pada orang-orang yang diperintah. Kata-kata "mengacu pada" tidak secara tegas mengandaikan cara tertentu dalam melakukan acuan. Hal itu, misalnya tidak mengandaikan demokrasi dalam bentuk apa pun, pemerintah politis bisa jadi bersifat otoriter atau monarki. Namun, batasan itu berarti bahwa penguasa melakukan upaya untuk mendamaikan berbagai kepentingan pihak yang dikuasainya. Yang penting adalah penguasa mempertimbangkan dampak yang akan ditimbulkan pemerintahannya dan tentu saja mempertimbangkan bagaimana ia harus bertindak sehingga pemerintahnya dapat terus berlanjut.

Terdapat dua bentuk teori politik yang secara analitis berbeda namun saling berhubungan. Pertama, teori politik perskriptif, yaitu teori tentang

\footnotetext{
${ }^{3}$ Peter H. Merkl. 1967. "Continuity and Change”. New York: Harper and Row, hal. 13.

${ }^{4}$ Rod Hague et al. 1998. "Comparative Government and Politics". London: Macmillan Press, hal. 3.

5 Andrew Heywood. 1997. "Politics". London: Macmillan Press, hal. 4.
} 
bagaimana pemerintah harus dijalankan. Teori ini menetapkan batasan-batasan bagi pemerintah dengan cara menganalisis konsep-konsep yang relevan, misalnya kesetaraan, hak, kebebasan, kewajiban dan keadilan, yakni berbagai cita-cita yang harus diwujudkan atau tidak dirusak oleh pemerintah jika pemerintahan dianggap absah. Kedua, teori politik deskriptif, yang melihat bagaimana pemerintahan yang absah dijalankan, dengan cara menganalisis berbagai konsep dan fenomena seperti otoritas, kekuasaan, hukum, pengambilan keputusan dan pertimbangan.

Penekanan yang diberikan oleh kaum ortodoks terhadap politik sebagai bentuk pemerintahan yang khas, yang bersifat menengahi berbagai kepentingan dan dijalankan melalui lembaga-lembaga politik, telah mengarahkan para teoretisi dan ilmuan politik untuk memusatkan perhatian pada lembaga-lembaga tertentu: lembaga negara pembuat undang-undang(legislatif), eksekutif dan yudikatif serta berbagai badan di bawahnya, seperti birokrasi kesejahteraan, kepolisian, pengadilan dan lain sebagainya.

Salah satu aspek politik yang menyedot perhatian adalah kompetisi dalam memperebutkan kekuasaan untuk memerintah, karena itu para ilmuan politik memusatkan perhatian pada partai politik, fraksi, kelompok kepentingan dan pusat-pusat kekuasaan lain yang merupakan landasan potensial bagi klaim terhadap kekuasaan untuk memerintah atau merupakan landasan untuk memasuki kompetensi memperebutkan kekuasaan, misalnya kepentingan ekonomi atau militer.

Studi akademis ortodoks terhadap politik cenderung menjadi studi mengenai laki-laki dan maskulinitas. Penyebabnya adalah karena para teoretisi (baik klasik maupun modern) dan para komentator mendefinisikan politik sebagai urusan maskulin. Mereka melakukannya dengan mengacu pada pemahaman umum yang diterima mengenai femininitas. Mereka merumuskan dan mendefinisikan femininitas dengan cara tertentu untuk menjelaskan mengapa makhluk feminin yang bernama perempuan tidak dapat berpartisipasi dan menjadi bagian dalam politik. Aristoteles mendefinisikan "polis" sebagai suatu bentuk yang terpisah dan berlawanan dengan rumah tangga. Hegel dan Rousseau merumuskan sebuah teori gender untuk menampilkan perbedaan antara dunia publik yang politis dan dunia domestik yang privat. Para teoritisi liberal seperti Locke dan Mill, sebagai penganut individualisme, bersikap simpatik terhadap hakhak perempuan. Namun, karena menggunakan konsep yang sama mengenai dunia domestik versus dunia publik, pembedaan antara yang politis versus yang pribadi diterima begitu saja dan memperkukuh pengecualian perempuan sebagai perempuan dalam politik. 
Salah satu tugas pertama teori politik feminis adalah untuk mengungkap teori gender yang sebagian besar implisit, namun seringkali sangat eksplisit dalam tulisan teori-teori politik klasik maupun modern (Coolle, 1993). Seringkali diduga dan diyakini bahwa teori-teori gender dan pemikiran mengenai hubungan antar jenis kelamin yang kerap menarik perhatian para filsuf besar hanyalah merupakan keunikan yang khas, yang diakibatkan oleh zaman saat mereka hidup. Para feminis, berpandangan bahwa mereka berhak mempertanyakan mengapa pikiran cerdas yang tanpa ragu menantang pandangan umum zamannya dalam banyak hal, misalnya, pemikiran tentang sumber kekuasaan politik tetapi mereka tetap menjadi budak (dalam hal gender). Kedua, para feminis mengungkapkan bagaimana berbagai gagasan mengenai relasi politik, lembaga-lembaga politik dan aturan politik di análisis dengan mengacu pada teori gender dan hubungan yang wajar antar jenis kelamin.

\section{Feminisme: Gerakan Politik dan Teori Politik}

Aspek penting dari sumbangan feminisme terhadap teori politik adalah melalui praktik politik feminis. Feminisme merupakan ciri yang selalu hadir dalam masyarakat modern. Sebagai gerakan politik, feminisme melibatkan diri dalam politik dalam arti konvensional dan juga telah memperluas wilayah aksi politik dengan cara yang signifikan, baik cara praktis maupun teoritis.

Pertama, ada kampanye yang terorganisisi untuk menuntut tindakantindakan legislatif, misalnya pembuatan undang-undang untuk menjamin hak suara perempuan, memberikan hak kepemilikan pada perempuan, melegalkan aborsi atau menjamin kesetaraan kesempatan dalam pekerjaan dan kesejahteraan. Kampanye tersebut kerap kali diabaikan oleh para ilmuan dan sejarawan politik konvensional. Kedua, kampanye terorganisir untuk menuntut perubahanperubahan sosial lain yang bersifat nonlegislatif namun penting, misalnya tuntutan agar lebih banyak perempuan duduk dalam parlemen dan pemerintahan, lebih banyak perempuan memasuki posisi-posisi sosial yang berkuasa lainnya seperti dalam pekerjaan dan pendidikan (kampanye menuntut agar lembaga pendidikan, profesi atau jenis pekerjaan lainnya terbuka bagi perempuan merupakan hal yang relevan, kampanye juga menuntut kesempatan yang setara dalam organisasi seperti perusahaan dan klub, bagian perempuan dalam partai politik. Ketiga, ada banyak organisasi yang berhubungan dengan upaya memberikan tekanan untuk melakukan perubahan sosial formal, namun sebagian besar menfokuskan perhatiannya pada perubahan sosial informal, misalnya berbagai organisasi swadaya seperti layanan publik melalui telepon, tempat perlindungan bagi perempuan korban kekerasan atau jaringan perempuan pada 
pekerjaan-pekerjan tertentu. Keempat, berbagai organisasi yang dilengkapi oleh dan bergabung dengan organisasi budaya dan tempat-tempat bagi organisasi perempuan dengan segala aktivitasnya, seperti kelompok penerbitan, para pembuat film serta kelompok-kelompok teater, pertokoan, kafe, bar (Griffin, 1995; Lovenduski dan Randall, 1993; Kaplan, 1992).

Pada tiga puluh tahun terakhir ini, perubahan gaya hidup, perubahan nilai dan perubahan cara berhubungan dengan teman, rekan kerja, kerabat dekat, pasangan seksual, pasangan hidup serta anak-anak ditekankan sebagai hal-hal yang sangat penting dalam feminisme. Aktivitas budaya, diskusi antar pribadi dan kelompok swadaya dianggap sebagai cara transformasi sosial yang lebih penting ketimbang strategi politik konvensional berupa kampanye publik terorganisasi untuk menuntut perubahan administratif dan legislatif baik di tingkat nasional maupun lokal.

Poin teoretis penting sehubungan dengan bentuk-bentuk aktivisme kaum feminis adalah, perubahan dalam wilayah politik konvensional dan tindakan yang dilakukan dari dalam lembaga politik yakni perundang-undangan dan administrasi pemerintahan tidak akan membawa perubahan sosial yang benar-benar menghasilkan perubahan bagi kehidupan banyak orang. Dalam hal ini, feminisme tidaklah begitu berbeda dari sejumlah pandangan yang lain. Kaum Marxis misalnya, selalu berpandangan bahwa perubahan sosial hanya dapat dilakukan melalui perubahan ekonomi yakni, perubahan bukan ditingkat permukaan berupa distribusi barang-barang, namun di tingkat yang lebih mendalam dan mendasar yaitu pada tingkat produksi yang merupakan penyebabnya. Kaum konservatif berpandangan bahwa perubahan sosial hanya dapat terjadi secara organis atau perlahan-lahan dan harus berakar dalam cara hidup, tradisi dan berbagai bentuk hubungan sosial tradisional. Namun gagasan bersama ini kurang penting dibanding aspek yang menjauhkan feminisme dari teori dan tradisi sosial politik yang menjadi pesaingnya. Sejumlah kepustakaan lain ditujukan untuk melakukan kritik terhadap berbagai sistem pemikiran sosial dan politik misalnya kapitalisme, liberalisme, sosialisme, marxisme, konservatisme dan sebagainya.

Kesimpulan yang penting yang dibuat oleh para feminis adalah bahwa konsepsi gender, baik yang implisit maupun eksplisit dalam berbagai sistem pemikiran bukanlah unsur kebetulan, melainkan unsur yang penting, dan bukan juga unsur yang tidak bermakna. Seluruh analisis tersebut setidaknya bersifat preskriptif (analisis yang mengemukakan gagasan sistematis tentang bagaimana masyarakat seharusnya diatur). Namun demikian, gagasan-gagasan itu merasuk ke dalam konstitusi, sistem hukum dan lembaga-lembaga sosial politik lainnya, serta ke dalam budaya popular dalam masyarakat. Dengan demikian, bisa 
dikatakan bahwa gagasan-gagasan tersebut bersifat konstitutif. Oleh sebab itu, gagasan ideal mengenai gender yang terdapat dalam konservatisme dan liberalisme sangat mungkin terasa dalam kehidupan masyarakat yang sebenarnya.

Dalam membentuk teori politik feminis, serangkaian fenomena sosial yang berada di luar wilayah kerja negara dan lembaga politik konvensional harus dipertimbangkan. "Cara hidup" dan "tradisi" merupakan hal yang sangat penting karena keduanya sering kali merugikan kepentingan perempuan. Secara khusus, nilai-nilai yang berada di pusat relasi seksual tradisional memiliki arti penting dan bukan hanya nilai-nilai dan gagasan, namun juga berbagai praktik yakni cara-cara melakukan sesuatu yang diterima begitu saja, remeh temeh dan diyakini umum, yang dilandasi oleh asumsi tak terkatakan mengenai peran berdasar jenis kelamin, tentang bagaimana berperilaku yang wajar bagi seseorang.

Kaum feminis telah memusatkan perhatian pada posisi perempuan dalam pasar kerja dan properti, namun mereka melihat ini terkait dengan posisi perempuan dalam "dunia domestik". Reproduksi yakni melahirkan dan membesarkan anak, reproduksi tubuh dalam kerja domestik dan penyedia makanan adalah sama pentingnya dan bahkan secara sistematis berhubungan dengan pembagian beban dan imbalan di pasar melalui kerja yang mendapat upah dan gaji.

Secara positif, teori politik feminis melibatkan pembuatan model dan penelitian empiris mengenai hubungan antara berbagai peristiwa dan perubahan dalam pemerintahan negara dan kebijakan pemerintah, perubahan hukum dan hubungan sosial di berbagai lembaga seperti perusahaan dan rumah tangga, serta perubahan dalam tempat-tempat seperti jalan dan rumah.

\section{Kembali ke Politik}

Sebutan "politik feminis" menimbulkan pertanyaan tentang apa yang dimaksud dengan politik. Politik secara konvensional didefinisikan sebagai proses yang berhubungan dengan pemerintah yang menengahi berbagai kepentingan melalui lembaga-lembaga publik. Dalam tradisi politik Barat, perbedaan antara yang publik dan privat, antara politik dan nonpolitik, dianalisis dalam kerangka perbandingan antara maskulinitas dan femininitas, hal ini merupakan hubungan antara superioritas dan inferioritas, atau antara bernilai dan tidak bernilai. Marjinalisasi dan perendahan feminisme, baik sebagai teori maupun gerakan sosial dan politik, dalam ilmu dan teori akademis menegaskan nilai superior yang dilekatkan pada politik laki-laki. 
Terdapat beberapa kesulitan dalam menghadapi hal ini. Pertama, para feminis cenderung menolak politik itu sendiri sebagai permainan laki-laki. Tekanannya lebih diarahkan pada perubahan sosial dan transformasi melalui sarana selain politik. Kedua, meski demikian, ada sebuah pergerakan untuk membentuk ulang konsep dan praktik politik dengan menekankan bahwa aktivitas dalam kehidupan pribadi dan sosial merupakan suatu yang politis. Jelas ini menimbulkan potensi ketegangan atau bahkan ketidakkonsistenan. Kalangan feminis bukanlah satu-satunya pihak yang rentan terhadap ketegangan ini. Ada beberapa aliran dalam sejumlah tradisi politik di mana politik pada dirinya sendiri tidaklah dihargai secara tegas.

Kaum liberal misalnya, cenderung melihat ekonomi khususnya ekonomi pasar dunia di mana hubungan kontrak yang sukarela dimasuki oleh orang dewasa yang bebas dan otonom sebagai dunia kebebasan. Sebaliknya, politik merupakan dunia kekuasaan dan otoritas negara, sebuah dunia dimana individu harus mematuhi hukum dan bekerja sama dengan orang lain, sebuah dunia ketidakbebasan. Begitu juga dalam pemikiran liberal tradisional, dunia domestik merupakan dunia ketidakbebasan, dunia tumbuh, hubungan ekonomi yang intim dan seterusnya (Frazer, 1996).

Bagi para pemikir konservatif jika ada sesuatu yang tidak menarik mengenai politik, mereka memandang politik sebagai kegiatan perlawanan dan konflik ketimbang dunia dengan otoritas yang mapan. Kalangan konservatif memandang hubungan tradisional, hubungan antara majikan dengan budaknya, kepala rumah tangga dengan pelayannya, anak dan istri, sebagai hubungan manusia yang sebenarnya di mana orang tahu siapa diri mereka, tahu di mana tempatnya. Bagi konservatif tradisional, baik pasar dan kepentingan pribadi yang kentara serta hubungan kompetitifnya maupun dunia politik, yakni negara dengan kompetisi memperebutkan kekekuasaan untuk memimpin, merupakan tempat yang tidak menarik.

Kaum sosialis pun tidak menyukai politik, namun dengan alasan yang berbeda. Para pemikir sosialis, baik aliran Marxis yang menekankan hubungan produksi dan terutama kepemilikan alat produksi sebagai kunci dalam hubungan sosial, maupun aliran sosial demokratis yang lebih memikirkan distribusi barang, sama-sama memiliki keyakinan akan prospek masyarakat yang diatur secara masuk akal, dimana individu maupun kelompok akan mengatur diri dan pemerintahan akan beranjak maju ke arah hal-hal yang adil dan disepakati secara universal. Oleh karena itu, watak politis, antagonistik dan manipulatif pada pemerintah tidak disukai dan juga diharapkan akan diatasi. 
Kaum feminis mengalami kebingungan dalam hal ini. Kapan pun laki-laki cenderung mengatakan kepada perempuan, seperti yang sering mereka lakukan, perempuan sebaliknya tidak keberatan jika mereka tidak dilibatkan dalam perkerjaan, kerja upahan atau dalam kekuasaan publik, karena hal tersebut lebih merupakan beban ketimbang keistimewaan. Perempuan berhak merespons dengan pedas jika demikian persoalannnya. Laki-laki tidak seharusna melakukan banyak kekerasan dan agresi baik formal maupun informal, yang bertujuan menjaga agar perempuan tidak dilibatkan. Artinya suatu kebaikan jika sedemikian dicemburui oleh laki-laki adalah benar-benar merupakan kebaikan.

Di sisi lain, kalangan feminis cenderung ikut bersikap antipati terhadap politik dalam pengertian tradisionalnya. Seperti halnya kaum sosialis, banyak feminis berharap dan bertujuan pada pengaturan diri yang benar-benar mandiri secara kolektif, yakni pengaturan berdasarkan rasio. Dalam kasus mereka, ada alasan tambahan untuk meninggalkan politik dalam pengertian tradisionalnya, yakni hubungan historis politik dengan maskulinitas. Karena itu sebagai suatu gerakan sosial dan politik, feminisme menolak berbagai bentuk oraganisasi tradisional, khususnya partai politik yang biasanya mengadakan pertemuan dan seterusnya. Sedikitnya terdapat perasaan mendua mengenai tujuan memasukan lebih banyak perempuan ke dalam parlemen; ada keyakinan yang luas bahwa perubahan legislatif dan administratif tidak dapat menjadi tujuan utama.

Pemerintahan yang menjalankan fungsi penengah melalui lembagalembaga negara dan publik adalah definisi dari politik yang ortodoks, bahkan dengan menggunakan definisi ini, bisa memberikan makna analitis yang jelas terhadap slogan "yang personal yang politis". Terdapat hubungan yang jelas antara pembagian kerja domestik dan partisipasi perempuan di dunia politik, yakni bidang politik konvensional. Kerugian dalam bidang "privat", "domestik" atau "personal" dibawa dan meluber ke dunia politik yang politis. Pemerintahan negara, perundang-undangan serta adminstrasi merupakan produk dari "privat". Siapa yang secara legal dapat melakukan hubungan seksual dengan siapa, aspek distribusi kekuasaan dan barang dalam keluarga, serta pembagian kerja domestik itu sendiri akan dipengaruhi dan ditetapkan langsung oleh perundang-undangan dan administrasi. Perundangan dan administrasi dipengaruhi dan dibatasi oleh berbagai pandangan dan praktik dalam masyarakat. Berbagai kebijakan dirancang dan diatur menurut definisi sosial mengenai hubungan sosial, mengenai apa yang dianggap normal dan seterusnya. Oleh karena itu, pengertian konsep-konsep tertentu, maskulinitas dan femininitas yang terbentuk dan dilanggengkan dalam masyarakat, budaya poluler, budaya tanding dan dalam berbagai praktik secara langsung sangat relevan bagi kebijan dan proses-proses politis di mana kebijakan tersebut dirancang. 
Politik sebagai proses yang berhubungan dengan upaya melanggengkan dan menggunakan kekuasaan untuk memerintah. Definisi ini tidak mengecualikan peraturan berbagai lembaga sosial: perusahaan, sekolah, organisasi sukarela dan rumah tangga dari wilayah politik. Definisi ini juga tidak menutup kepentingan adanya cara tertentu dalam memerintah. Kekuasaan untuk memerintah mungkin disokong oleh kekuasaan ekonomi, sosial, budaya, seksual ataupun kekuasaan tradisional. Di mana pun ada individu yang diperintah, di sana terdapat pertanyaan tentang keabsahan pemerintah. Ada juga berbagai proses untuk menjaga, menggunakan dan menentang kekuasaan untuk memerintah: berbagai proses dan kegiatan inilah yang membentuk politik.

Pendapat ini menjelaskan mengapa kritik atas perbedaan "publik versus privat" merupakan hal yang sangat sentral dalam teori feminis. Argumen tersebut mengarahkan untuk menantang, bahkan membongkar berbagai perbedaan dengan tegas (Pateman, 1989). Namun demikian, penting juga aga selanjutnya "publik dan privat" di bangun ulang (Squires, 1994). Para feminis berpendapat, pandangan umum bahwa relasi domestik atau seksual itu bersifat privat haruslah ditantang. Namun tidak berarti ada pengawas pemerintah di tiap kamar tidur dan kamar mandi untuk mengatur perilaku seksual (seperti yang dipahami oleh beberapa pengkritik feminisme dari kalangan liberal mengenai apa yang dimaksud kaum liberal (Frazer dan Lacey, 1993). Dan tidak diragukan lagi, bahwa dalam beberapa konteks privasi merupakan sesuatu yang bernilai.

Demikian halnya dengan publisitas dan kehidupan publik juga merupakan hal yang bernilai, beberapa kritikus mulai menyuarakan kekhawatiran terhadap perhatian feminisme yang dipusatkan pada urusan antar pribadi dan mengajukan pandangan bahwa kaum feminis tidak boeh lupa akan pentingnya publisitas yakni berbicara dan bertindak di wilayah publik dengan tujuan agar suara mereka di dengar dan tindakan mereka dilihat oleh publik (Dietz, 1991, 1992). Hal ini telah dibahas dalam teori demokrasi feminis dan teori keadilan feminis yang memusatkan perhatian pada hambatan tertentu dalam pidato, debat dan aksi publik. Pertanyaan mengenai batas-batas publisitas dan privasi, jenis lembaga di mana perempuan dan berbagai suara lain yang sampai saat ini masih marjinal dapat didengarkan secara layak dam di mana standar pertimbangan dan perdebatan publik dapat ditingkatkan serta landasan yang tepat bagi kekuasaan politik merupakan hal terpenting dalam agenda teori feminis.

\section{Daftar Pusataka}


Budiardjo, Miriam. 2009. Dasar-dasar Ilmu Politik. Jakarta: PT Gramedia Pustaka Utama

Coole, Diana. 1993. Women in Political theory: From Ancient Misogyny to Contemporary Feminism, ed 2. Hemel Hempstead: Hasvester Wheatsheaf

Dietz, Mary G. 1991. Hannah Arendt and Feminist Politics dalam Mary Lyndon Shanley dan Carole Pateman (ed.) Feminist Interpretations and Political Theory. Cambridge: Polity Press 1992. Feminism and Theories of Citizenship dalam Chantal Mouffle (ed.) Dimension of Radical Democracy. London: Verso

Firestone, Shulamith. 1970. The Dialectic of Sex: The Case for Feminist Revolution. New York: William Morrow

Frazer, Elizabeth. 1996. Feminist and Liberalism dalam James Meadowcroft (ed.) The Liberal Political Tradition: Contemporary Reappraisal. London: Edward Arnold Griffin, Gabriele. 1995. Feminism Activism in the 1990s. London: Taylor and Francis

Heller, Agnes. 1991. The Concept of the Political Revisited dalam David Held (ed) Political Theory Today. Oxford: Polity

Jackson, Stevi dan Jackie Jonas. 1998. Pengantar Teori-teori Feminis Kontemporer. Yogyakarta: Jalasutra.

Kaplan, Gisela. 1992. Contemporary Western European Feminism. London: UCL Press Millet, Kate. 1977. Sexual Politics. London:Virago

Pateman, Carole. 1988. The Sexual Contract. Oxford: Polity Press

Squires, Judith. 1994. Private Lives, Schedule Places: Privacy as Political Possibility. Environment and Planning D: Society and Space 